\title{
Preliminary field study on saddle pressure distribution in horses without back pain
}

\author{
Melanie Glaus', Stefan Witte ${ }^{2}$ and Conny Herholz' \\ ${ }^{1}$ Bern University of Applied Sciences, School of Agricultural, Forest and Food Sciences HAFL, CH-Zollikofen \\ 2 Vetsuisse Faculty Bern, ISME Equine Clinic, CH-Bern
}

\begin{abstract}
Summary: Objective of the study was to assess saddle pressure distribution in a normal horse population and to determine whether or not the pressure pad used is able to provide reliable information on saddle fit in a field setting. In addition the influence of type of saddle, type of saddle pad and back conformation on saddle pressure distribution was investigated. Forty randomly sampled horses were equipped and measured with a pressure pad at rest, during free and medium (collected) walk and during rising and sitting trot. All measurements were made on the straight line and were summarized according to the percentage pressure distribution front to back, as well as left, right and middle (spinal), of the saddle. Additional data were collected by a questionnaire and all data were statistical analyzed by the program STS 3.42 and NCSS 2007 (ANOVA). Significantly higher percentage pressures were noted at the back of the saddle in horses with poor musculature in the lumbar region when compared with those with prominent muscles in this area. Measurements using alternative saddle pads such as gel pads, foam material pads or yoga mats were variable and gave significantly different (higher) percentage pressures when compared to the traditional thin textile saddle pad. Western saddles showed significantly higher percentage pressure distribution towards the front of the saddle while a treeless saddle showed a higher percentage pressure distribution over midline. This study provides preliminary information on the saddle pressure distribution in a normal horse population measured in the field setting. Larger numbers would enable more robust interpretation of pressure measurements and improve on their clinical relevance.
\end{abstract}

Keywords: Saddle pressure distribution / field study / saddle type / saddle pad / back / orthopedics

Citation: Glaus M., Witte S., Herholz C. (2015) Preliminary field study on saddle pressure distribution in horses without back pain. Pferdeheilkunde 31, 145-152

Correspondence: Conny Herholz PD Dr. med. vet., HAFL Zollikofen, Länggasse 85, 3052 Zollikofen, Schweiz, e-mail: Conny.herholz@bfh.ch

\section{Introduction}

It has been estimated that $75 \%$ of the horses are ridden with a saddle which does not fit (Harman 2004). An ill-fitting saddle is one of the main causes of back pain (Fruewirth et al. 2004), but it may simply manifest as poor performance, in particular in the sport horse (Harman 1994, Werner et al. 2002). Distinct differences in the heigh of pressure and its distribution are correlated with saddlefit (Mönckemöller et al. 2005). The primary causes of an ill-fitting saddle are asymmetry of the saddle, cushions that are too hard and a caudally located center of balance (Nykios et al. 2005). Damages related to pressurer are caused both by intensity of the rider's action and the duration of it (von Peinen et al. 2010b).

Judging saddle fit is most often performed subjectively and with the horse at rest (von Peinen 2006). Use of a saddle pressure measurement device allows objective assessment of pressures and their distribution under the saddle, during ridden exercise (Harman 1994, Werner et al. 2002, Nyikos et al. 2005). The pressure data generated by the Pliance-System has been validated and reported extensively with reference to saddle fit, saddle type, saddle pad, and in the evaluation of horse, saddle and rider interactions (Nykios et al. 2005, von Peinen et al. 2010, Latif et al. 2010, Kotschwar et al. 2010 a, Fruewirth et al. 2004). As part of an evolving process these studies aimed to improve the reliability, accuracy and clinical relevance of saddle pressure measurement devices. The single most important factor in all of these studies is the standardization of the experimental setting (i.e. rider, speed, ground) (Pul- lin et al. 1996, De Cocq et al. 2006), something that is not always taken into consideration by saddlers and trainers that use saddle pressure measurement devices in their daily work. The aim of the study was to investigate the use of a commercially available saddle pressured measurement device under field conditions and to identify commonalities with standardized studies. A further goal was in providing preliminary guidelines for the interpretation of information generated with the unit. In order to fulfill these goals the following hypotheses were tested:

- Gait will significantly influence pressure distribution.

- The structural differences between dressage, show jumping and eventing saddles and western and treeless saddles will result in significantly different pressure distributions (frontback, left-right and spine)

- Saddle pads have the potential to negatively influence the normal pressure distribution under all saddles in which they are used.

- Conformation of the longitudinal muscles of the vertebral column will significantly influence pressure distribution under a saddle.

\section{Materials and methods}

Horses, riders and saddles

Saddle pressure distribution was measured in 40 randomly sampled normal horses without a history of back pain. This included 19 mares and 21 geldings, with an age range of 5 
to 22 years (mean 11.5 years). Horse breeds included in the study were warmbloods, thoroughbreds, arabians, Swiss light draft horses (Freiberger) and ponies. Breeds were grouped as heavy $(\mathrm{He})$, warmblood (WB), thoroughbred / arabian (TB/A) and small horse / pony (Po) Horses were reported as being used in dressage, show jumping or for pleasure riding. Photographs of all horses were taken at the time of the measurement and later used in order to categorize the degree of musculature (in the thoracolumbar region) as convex, flat or concave. Based on rider information it was established that none of the horses measured were suffering from clinically relevant back pain. Riders were specifically asked whether a veterinarian, chiropractor or osteopath had visited the horse for treatment of the thoracolumbar region. Horses were housed at various locations and for the purposes of the study were ridden by their usual rider using their own saddle and pad. Saddles measured included jumping $(n=13)$, dressage $(n=15)$, eventing $(n=8)$, western $(n=3)$ and treeless $(n=1)$ saddles. Saddle pads were categorized as regular cloth pad (RCP), wool pad (WP) or 'alternative' pad (AP). The riders were all experienced horsemen.

\section{Data acquisition}

All measurements were made at the horses' own stable. With the exception of 2 measurements (performed on a gravel pathway) all measurements were performed in sand arenas. All horses were ridden in a straight line and recorded in the same order (at rest, free walk, collected walk, rising trot and finally sitting trot). Recordings were made over 25 meters as defined by markers.

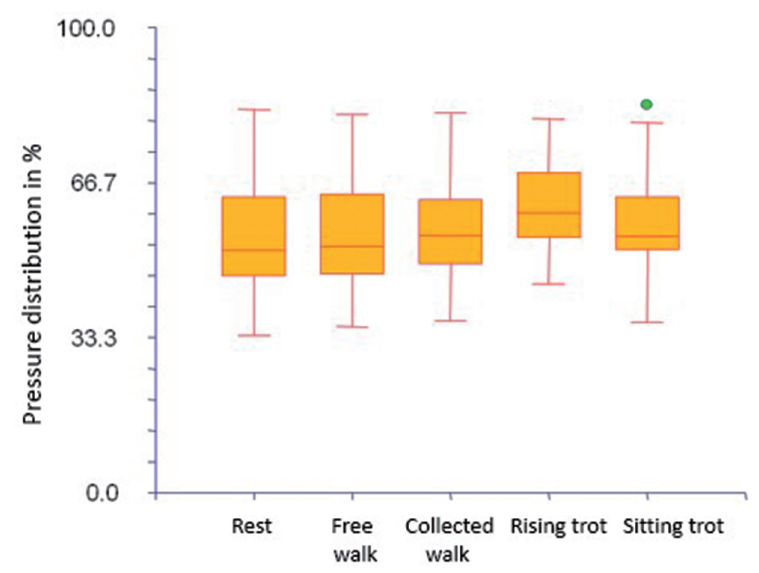

Fig. 1 Box plot of the median percentage pressure distribution, at the front of the pad, for all horses | Boxplot der prozentualen Druckverteilung im vorderen Bereich der Messmatte (alle Pferde)
Saddle pressure distributions were registered using the Team Satteltester ${ }^{\circledR}$ system. This system is marketed for use by saddlers, riding teachers and veterinarians. This system incorporates 256 flat pressure sensors arranged $16 \times 16$ as a square pad. Sensors record at a frequency of $20 / \mathrm{Hz}$ (Albrecht pers. comm. 2013). Pressure sensors are protected by a rubberized cloth giving the pad a thickness of $1.5 \mathrm{~cm}$ and allowing easy symmetrical placement under all saddles. Data was continuously transmitted via blue-tooth and recorded on a laptop computer. The mean pressure distribution recorded over each trail by the custom-made STS-program 3.42 was used for data analysis. Percentage pressure distribution was categorized as left, right and spinal (middle) as well as front and back.

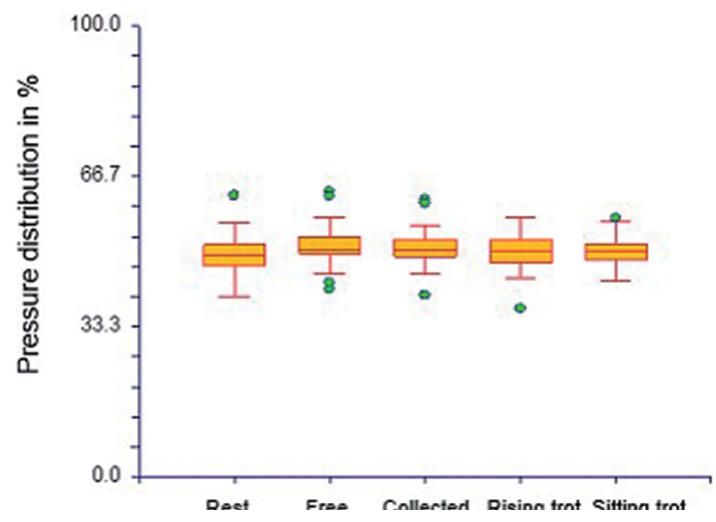

Fig. 2 Box plot of the median percentage pressure distribution measured on the left half of the pad, for all horses. Boxplot der prozentualen Druckverteilung auf der linken Seite der Messmatte (alle Pferde)

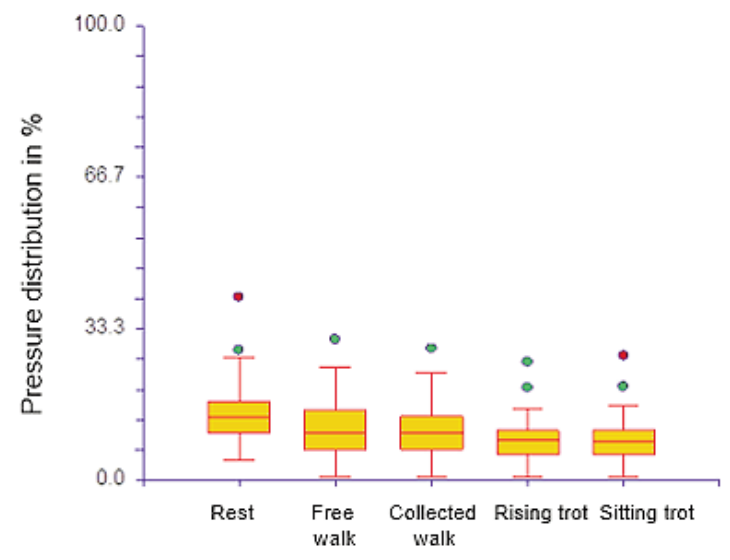

Fig. 3 Box plot of the median percentage pressure distribution, measured over the spine in all horses. | Boxplot der prozentualen Druckverteilung im spinalen Bereich der Messmatte (alle Pferde)

\begin{tabular}{|c|c|c|c|c|c|}
\hline \multirow[t]{2}{*}{ Condition } & Rest & Free Walk & Collected Walk & Rising Trot & Sitting Trot \\
\hline & & & $\%$ Distribution & & \\
\hline Median & 52.3 & 53.2 & 55.5 & 60.3 & 57.19 \\
\hline Minimum & 33.8 & 35.7 & 37.0 & 44.8 & 36.7 \\
\hline Maximum & 82.4 & 81.3 & 81.7 & 80.4 & 83.4 \\
\hline Range & 48.6 & 45.6 & 44.7 & 35.6 & 46.7 \\
\hline$p$ - value & 0.22 & 0.44 & 0.44 & 0.40 & 0.95 \\
\hline
\end{tabular}




\section{Statistical analysis}

Statistical analysis of the data was performed using the NCSS program. Normal distribution of the data was tested using the Kolmogorov-Smirnov test. The influence of various factors (saddle type, saddle pad and back conformation) were tested separately using an ANOVA. In cases where normal distribution was not given, a Kruskal-Wallis Anova on Ranks was used. Significance level was set at $p<0.05$.

\section{Results}

Influence of gait on pressure distribution

Pressure distribution front to back

Percentage pressures in a craniocaudal direction were registered as front or back. For ease in reporting the results of only the percentage distribution towards the front will be reported. Although median values for the trot appear greater than those for the other conditions, a significant difference is only present between rest and sitting trot $\left(p=0.027^{*}\right)$ (Fig. 1 and Tab. 1).

Pressure distribution left to right

In order to allow a direct comparison between left and right the pressure values obtained for the spine (midline) were discounted and the values for left and right corrected to give a percentage distribution to a side. Figure 2. shows the tight distribution of median pressure measurements, in our population of horses, with an equal left to right distribution. Median pressure distribution was confirmed to lie around $50 \%$ with a range of approximately $10 \%$ to either side. There were no statistically significant differences in these findings between the gaits measured.

Spinal

The percentage pressure distribution for pressures measured over the spine (midline), during the various gaits, are shown in figure 3. Significantly lower values were recorded when horses were measured during both sitting and rising trot when compared to the resting state $\left(p=0.000131^{*}\right)$. The mean percentage pressure located over the spine was $11.5 \%$.

\section{Factors influencing percentage pressure distribution}

Saddle-type, saddle pads and back conformation were evaluated for their possible influence on pressure distribution and are summarised in tables 2, 3 and 4 . Significance is highlighted through an asterisk.

Type of Saddle

At rest $(p=0.003)$ and at ridden walk $(p=0.0136$ and $p=0.003$ ) there is a significantly greater mean percentage pressure over the front of the western saddle (WE) when compared to the dressage (DR), show jumping and eventing

Table 2 Differences in mean percentage pressure distribution according to condition and between types of saddle (DR= Dressage, SJ=Show Jumping, $\mathrm{EV}=$ Eventing, $\mathrm{WE}=$ Western, $\mathrm{TL}=$ Treeless) $\mid$ Unterschiede der prozentualen Verteilung (Mittelwerte) bezogen auf Gangart und Satteltyp $(D R=$ Dressur, $S J=S$ pringen, $E V=$ Eventing, $W E=$ Western, $T L=$ Baumlos $)$

\begin{tabular}{|c|c|c|c|c|c|c|c|}
\hline \multirow[b]{2}{*}{ Type of saddle } & \multicolumn{5}{|c|}{ Mean percentage pressure distribution } & \multirow[t]{2}{*}{$\mathrm{p}$-Value } & \multirow[t]{2}{*}{ Significant differences } \\
\hline & $\begin{array}{c}\text { DR } \\
\mathrm{n}=15\end{array}$ & $\begin{array}{c}\text { SJ } \\
n=13\end{array}$ & $\begin{array}{c}E V \\
n=8\end{array}$ & $\begin{array}{c}W E \\
n=3\end{array}$ & $\begin{array}{c}\mathrm{TL} \\
\mathrm{n}=1\end{array}$ & & \\
\hline \multicolumn{8}{|c|}{ Front } \\
\hline Rest & 49.51 & 56.73 & 55.84 & 78.23 & 57.1 & $0.003^{*}$ & 1. WE ↔ DR, SJ,EV \\
\hline Walk & 50.13 & 57.16 & 54.16 & 73.4 & 61.3 & $0.0136^{*}$ & 1. WE $\leftrightarrow \mathrm{DR}$ \\
\hline Collected walk & 51.99 & 57.57 & 56.11 & 76.5 & 64.8 & $0.003^{*}$ & 1. WE $\leftrightarrow \mathrm{DR}, \mathrm{SJ}, \mathrm{EV}$ \\
\hline Rising trot & 58.06 & 62.28 & 61.78 & 74.73 & 68.8 & 0.075 & None \\
\hline Sitting trot & 54.47 & 58.5 & 58.65 & 67.2 & 68.3 & 0.261 & None \\
\hline \multicolumn{8}{|c|}{ Left } \\
\hline Rest & 50.46 & 47.66 & 48.54 & 50.5 & 53.6 & 0.158 & $\begin{array}{c}\text { None } \\
\text { 1. SJ } \leftrightarrow W E, T L\end{array}$ \\
\hline Walk & 51.01 & 49.96 & 50.53 & 57.33 & 62.3 & $0.001^{*}$ & $\begin{array}{l}\text { 2. } E V \leftrightarrow W E, T L \\
\text { 3. } D R \leftrightarrow W E, T L\end{array}$ \\
\hline Collected walk & 51.35 & 48.94 & 50.3 & 55.23 & 60.7 & $0.0195^{*}$ & 1. SJ $\leftrightarrow \mathrm{WE}, \mathrm{TL}$ \\
\hline Rising trot & 50.16 & 48.35 & 50.36 & 54.1 & 57.7 & $0.005^{*}$ & None \\
\hline Sitting trot & 50.08 & 49.53 & 49.4 & 52.03 & 57.3 & 0.0736 & None \\
\hline \multicolumn{8}{|c|}{ Spinal } \\
\hline Rest & 12.05 & 15.12 & 15.86 & 13.93 & 40.3 & $0.0018^{*}$ & 1. TL $\leftrightarrow \mathrm{DR}, \mathrm{WE}, \mathrm{SJ}, \mathrm{EV}$ \\
\hline Walk & 8.15 & 13.99 & 12.03 & 11.8 & 31 & $0.0044^{*}$ & 1. $\mathrm{TL} \leftrightarrow \mathrm{DR}, \mathrm{EV}$ \\
\hline Collected walk & 7.61 & 11.47 & 12.75 & 9.63 & 29 & $0.0068^{*}$ & 1. TL $\leftrightarrow \mathrm{DR}, \mathrm{WE}, \mathrm{SJ}$ \\
\hline Rising trot & 7.01 & 9.48 & 10.11 & 6.9 & 26 & $0.0014^{*}$ & 1. $\mathrm{TL} \leftrightarrow \mathrm{WE}, \mathrm{DR}, \mathrm{SJ}, \mathrm{EV}$ \\
\hline Sitting trot & 7.34 & 9.26 & 10.59 & 5.07 & 27.4 & $0.0007^{*}$ & 1. TL $\leftrightarrow W E, D R, S J, E V$ \\
\hline
\end{tabular}


saddle (Tab. 2). A further significant difference is noted between a left-sided distribution of mean pressures in western and treeless saddles, when compared to the other saddletypes ( $p=0.001, p=0.005)$. Finally the treeless saddle showed a significantly higher mean percentage distribution over the spine (midline) than all other saddle types $(p=0.0018$, $p=0.0044, p=0.0068, p=0.0014, p=0.0007)$. The highest value $(40.3 \%)$, was measured at rest.

Saddle pad

At rest and at a walk the mean percentage pressure distribution was significantly higher $(p<0.05)$, towards the front of the saddle and over the spine, under the 'alternative' saddle pads (Yoga mat, Gel pad or similar), than with the regular cloth pad (Tab. 3).

\section{Conformation}

A concave lumbar region resulted in a significant increase in mean percentage pressure distribution to the back of the saddle when compared to a convex conformation (Tab. 4). This was recorded in all 5 conditions $(p=0.021, p=0.023$, $p=0.015, p=0.017, p=0.022)$.

\section{Discussion}

Pressure distribution and influence of gait

The results of our study suggest that, irrelevant of gait, variability in pressure distribution front to back of up to $30 \%$ can be normal. This finding corresponds to those of de Coq et al (2006) and Nyikos et al. (2005) which describe high variability in maximal pressure measurements of $23 \%$ and $35 \%$ respectively.

With outliers excluded the variation in left to right percentage pressure distribution is small and variations, in the mean, of greater than 5-10\% can be interpreted as abnormal. Higher percentage distribution to one side should not be ignored and its possible clinical relevance must be correlated with the results of a thorough clinical evaluation.

In the presence of an adequate depth and width of gullet no pressure should be registered on midline (Weiss 2013). Despite this a mean percentage pressure distribution of $11.5 \%$ was measured in our study. Interestingly this value was significantly lower at the trot than at rest. The authors suggest contraction of the epaxial muscles of the back (primarily $\mathrm{m}$. longissimus dorsi) and their stabilizing role during exercise as an explanation for these findings, the saddle being 'lifted' from the spine.

As already mentioned results of the current study show a consistently higher mean percentage pressure over the front half of the saddle. This finding has been reported previously (Nyikos et al. 2005). During ridden exercise this trend is exacerbated by the large influence of rider and his or her seat (de Coq et al. 2009, Peham et al. 2010). Fruewirth et al. (2004) shows, that at walk the overall force is more or less equivalent to the rider's body mass, whereas the force values increase to about twice the body mass of the rider at a trot. Instability of an ill-fitting saddle may cause additional pressure peaks resulting from a reduced coupling of the saddle between horse movements and rider movements (Meschan et al. 2007). An increasing mean pressure distribution towards the front of the

\begin{tabular}{|c|c|c|c|c|c|}
\hline \multicolumn{6}{|c|}{$\begin{array}{l}\text { Table } 3 \text { Differences in mean percentage pressure distribution according to condition and between saddle pad ( } \mathrm{RCP}=\text { regular cloth pad, } \\
\mathrm{WP}=\text { wool pad, } \mathrm{AP}=\text { alternative pad | Unterschiede der prozentualen Verteilung (Mittelwerte) bezogen auf Gangart und Sattelunterlagen } \\
(\mathrm{RCP}=\text { einfaches Sattelpad, WP=Fellunterlage, AP=alternative Pads wie Gelpad oder Yogamatte) }\end{array}$} \\
\hline \multirow{3}{*}{ Saddle pad } & \multicolumn{3}{|c|}{ Mean } & \multirow{3}{*}{$p$-Value } & \multirow{3}{*}{ Sigificant differences } \\
\hline & RCP & WP & AP & & \\
\hline & $\mathrm{n}=20$ & $n=11$ & $\mathrm{n}=9$ & & \\
\hline \multicolumn{6}{|c|}{ Front } \\
\hline Rest & 50.75 & 57.2 & 63.83 & $0.0204^{*}$ & 1. $\mathrm{RCP} \leftrightarrow \mathrm{AP}$ \\
\hline Walk & 50.27 & 57.75 & 63.89 & $0.005^{*}$ & 1. $\mathrm{RCP} \leftrightarrow \mathrm{AP}$ \\
\hline Collected walk & 52.3 & 59.66 & 63.24 & $0.018^{*}$ & 1. $\mathrm{RCP} \leftrightarrow \mathrm{AP}$ \\
\hline Rising trot & 58.59 & 62.65 & 64.49 & 0.063 & None \\
\hline Sitting trot & 59.6 & 55.1 & 59.6 & 0.206 & None \\
\hline \multicolumn{6}{|c|}{ Left } \\
\hline Rest & 49.81 & 49.03 & 48.9 & 0.833 & None \\
\hline Walk & 50.39 & 52.28 & 52.39 & 0.354 & None \\
\hline Collected walk & 49.87 & 51.77 & 52.04 & 0.272 & None \\
\hline Rising trot & 49.43 & 50.7 & 50.77 & 0.715 & None \\
\hline Sitting trot & 49.67 & 50.5 & 50.49 & 0.691 & None \\
\hline \multicolumn{6}{|c|}{ Spinal } \\
\hline Rest & 13.45 & 16.98 & 15.4 & 0.751 & None \\
\hline Walk & 9.02 & 13.4 & 15.46 & $0.035^{*}$ & 1. $\mathrm{RCP} \leftrightarrow \mathrm{AP}$ \\
\hline Collected walk & 8.02 & 11.91 & 14.64 & $0.022^{*}$ & 1. $\mathrm{RCP} \leftrightarrow \mathrm{AP}$ \\
\hline Rising trot & 7.16 & 10.15 & 11.261 & 0.0759 & None \\
\hline Sitting trot & 6.9 & 10.7 & 11.3 & 0.0505 & None \\
\hline
\end{tabular}


saddle is noted in our results progressing from standing through walk to the trot (sitting trot creating less pressure than rising trot). Hypothesis one can therefore be upheld. Results of a previous study showed that the centre of pressure shifts toward the withers in sitting and rising trot (Peham et al. 2010) and, as seen in our study, that pressures are highest at the front (third) of the saddle during rising trot (Latif et al. 2010). Regarding propre saddle fit in the area of the gullet plate and stainless steels possible discrepancies are best manifested at rising trot as well (von Peinen et al. 2010b). It is important to remember that speed will also influence tension through the horse's back (Robert et al. 2001) and therefore pressure distribution. Speed was a factor that was not standardised in this study as horses moved at their preferred speed.

Influence of various factors on percentage pressure distribution

Type of saddle

Dressage saddles appear to have a front-back distribution that most closely approximates 50:50. Aside from good saddle fit this may be a reflection of the importance of a correct seat in this discipline. Significantly higher values were measured towards the front in the three western saddles included in the study (Table 3.) when compared to all other saddle types. The tendency of these saddles to 'tip' forward has been shown previously (Cockerham et al. 2010) and it is likely that this results from the rigid wooden saddle tree.

The significant differences in mean percentage pressure distribution to the left in both the treeless and the western saddles compared to the other saddle types is likely explained by their proven relative lack of stability (Belock et al 2012). Finally the absence of a saddle tree leads to poor weight distribution and the significant focal pressure over midline recorded in the 'treeless saddle' (Belock et al. 2012, Latif et al. 2010). The highest percentage pressure distribution measured over midline in this study was $40.4 \%$. This was recorded in the only horse fitted with a treeless saddle. This saddle-type is known to cause focal pressure over the spine (Belock et al. 2010, Latif et al. 2010). Although only a low number of saddles of this two types were included in the study $(n=3 ; n=1)$, the results confirm that particular attention should be paid to the type of saddle in order to avoid future problems. Hypothesis two can be upheld.

\section{Saddle pad}

Good saddle-fit is paramount for long term health of the back and poor fit is hardly compensated through the use of a pad (Harman et al. 2004). Kotschwar et al. (2010 b) came to the conclusion that the saddle pads tested in their study (gel, leather, foam and reindeer) did not greatly influence the fit of a saddle that was appropriate for the horse. However the reindeer fur pad alone decreased the maximum overall force. A chosen pad should be large enough, not create bulges, not slip during movement, have an appropriate shape at the withers and should not cause an excessive narrowing of the saddle (Kotschwar et al. 2010 b). Bearing the findings of Kotschwar et al (2010 b) and Harman et al (2004) in mind the 'alternative' pads in table 3 can be seen to negatively influence percentage pressure distribution (significant shift of pressure to the front of the saddle and significant increase in pressure over the spine). Hypothesis three can also be upheld. A saddle that fits well and is combined with a simple cloth pad (numnah) appears

\begin{tabular}{|c|c|c|c|c|}
\hline \multirow[b]{2}{*}{ Back conformation } & \multicolumn{2}{|c|}{ Mean } & \multirow[t]{2}{*}{$p$-Value } & Significant differences \\
\hline & $\begin{array}{c}\text { Convex } \\
n=27\end{array}$ & $\begin{array}{c}\text { Concave } \\
n=13\end{array}$ & & \\
\hline \multicolumn{5}{|c|}{ Front } \\
\hline Rest & 59.08 & 47.64 & $0.021^{*}$ & 1. Convex $\leftrightarrow$ Concave \\
\hline Walk & 58.69 & 48.21 & $0.023^{*}$ & 1. Convex $\leftrightarrow$ Concave \\
\hline Collected walk & 60.01 & 49.63 & $0.015^{*}$ & 1. Convex $\leftrightarrow$ Concave \\
\hline Rising trot & 64.78 & 55.65 & $0.017^{*}$ & 1. Convex $\leftrightarrow$ Concave \\
\hline Sitting trot & 61.07 & 51.71 & $0.022^{*}$ & 1. Convex $\leftrightarrow$ Concave \\
\hline \multicolumn{5}{|c|}{ Left } \\
\hline Rest & 49.68 & 48.99 & 0.745 & None \\
\hline Walk & 51.88 & 50.28 & 0.541 & None \\
\hline Collected walk & 51.51 & 49.55 & 0.354 & None \\
\hline Rising trot & 50.48 & 49.27 & 0.649 & None \\
\hline Sitting trot & 50.26 & 49.75 & 0.888 & None \\
\hline \multicolumn{5}{|c|}{ Spinal } \\
\hline Rest & 14.36 & 15.67 & 0.798 & None \\
\hline Walk & 10.97 & 12.9 & 0.609 & None \\
\hline Collected walk & 9.1 & 12.05 & 0.481 & None \\
\hline Rising trot & 8.53 & 9.79 & 0.764 & None \\
\hline Sitting trot & 8.56 & 9.94 & 0.761 & None \\
\hline
\end{tabular}


to distribute pressure best. Also Mönckemöller et al. 2005 showed that after proper saddle fitting the horse's back pain could be reduced considerably.

\section{Back conformation}

Conformation and condition of muscles in the thoracolumbar region dictate how well a particular saddle will fit. In the current study shape of the withers did not appear to influence percentage pressure distribution. In contrast to this a lack of muscles (and concave conformation) in the lumbar region was shown to be associated with increases in mean percentage pressure distribution towards the back of the saddle This likely results from a backward tipping of the saddle, applying focal pressure. This will eventually lead to muscle soreness (Harman 2004, Nyikos 2010). A convex lumbar region was noted to shift pressures to the front of the saddle. Hypothesis four is therefore partially upheld.

As the goal of the study was to assess the value of saddle pressure measurements by saddlers or trainers under field conditions, horses were not clinically examined to rule out back pain prior to inclusion in the study. Undiagnosed thoracolumbar pain can therefore not be excluded. A clinical examination and ideally further diagnostics, including radiographs of the thoracolumbar vertebral column, would have been necessary to confirm its absence.

Horses included in the study were randomly selected rather than being assigned to a group or fulfilling inclusion criteria. This excluded bias but resulted in relatively low numbers in certain categories. For this reason the statistical power is often poor. Future studies should include larger numbers of horses allowing more robust comparison between conditions and influencing factors. Repeatability should also be assessed. Nevertheless, important trends have been evaluated.

While this study divided the back into regions through the categories front, back, left, middle (spinal) and right, a more accurate subdivision would more precisely localise sites of abnormal pressure. In addition the system used for this study is unable to provide absolute pressure measurements. Although such measures must be interpreted in conjunction with clinical findings and the horse's constitution, they provide valuable additional information on the actual forces to which the back is being subjected.

Bearing these limitations in mind the current study provides preliminary data useful for the interpretation of percentage pressure distribution data recorded using a saddle pressure measurement system in a field setting. It also provides some insight into factors that should be considered due to their influence on pressure and pressure distribution. Larger numbers are required to confirm these initial findings. It is important to remember that the results of an isolated (or repeated) saddle pressure measurement represent a small part of a larger evaluation that recognises the interactions between saddle, horse and rider.

\section{Manufacturer's address}

Team-Satteltester: David Albrecht, Cetin Ekin GbR, Schlossstr. 52D, 86485 Biberbach-Markt, Germany

\section{Animal Welfare Statement}

For the present study no approval was necessary as all horses were ridden under normal conditions and no surgical or other medical procedure was adopted.

\section{Conflict of interest statement}

The authors exclude any conflict of interest.

\section{References}

Belock B., Kaiser L. J., Lavagnino M., Clayłon H. M. (2012) Comparison of pressure distribution under a conventional saddle and a treeless saddle at sitting trot. Vet. J. 193, .87-91

Cockerham S. (2010) Saddle Fit Study in the Western Saddle Market. National Agri-Marketing Club, abgerufen am 26.08.2013, http://aces.nmsu.edu/academics/aeab/documents/nmsu-saddlestudy-2010-final.pdf

De Cocq P., van Weeren P. R., Back W. (2006) Saddle pressure measuring: Validity, reliability and power to discriminate between different saddle-fits. Vet. J. 172, 265-273

Fruewirth B., Peham C., Scheidl M., Schobesberger H. (2004) Evaluation of pressure distribution under an English saddle at walk, trot and canter. Equine Vet. J. 36, .754-757

Harman J. C. (1994) Practical use of a computerized saddle pressure measuring device to determine the effects of saddle pads on the horse's back. Equine Vet. J. 14, .606-611

Harman J. C. (2004) The Horses Pain-Free Back and Saddle-Fit Book: Ensure Soundness and Comfort with Back Analysis and Correct Use of Saddles and Pads. Trafalgar Square Books, Vermont, pp. 218

Kotschwar A. B., Baltacis A., Peham C. (2010a) The influence of different saddle pads on force and pressure changes beneath saddles with excessively wide trees. Vet. J. 182, .322-325

Kotschwar A. B., Baltacis A., Peham, C. (2010b) The effects of differents saddle pads on forces and pressure distribution beneath a fitting saddle. Equine Vet. J. 42, 114-118

Latif S. N., von Peinen K., Wiestner T., Bitschnau C., Renk B., Weishaupt M. A. (2010) Saddle pressure patterns of three different training saddles (normal tree, flexible tree, treeless) in Thoroughbred racehorses at trot and gallop. Equine Vet. J. 42, 630-636

Mönkemöller S., Keel R., Hambsch D., Müller J., Kalpen A., Geu$\operatorname{der}$ M., Aver J. A., Von Rechenberg B. (2005) Pliance-Mobile16HE: Eine Folgestudie über elektronische Satteldruckmessungen nach Anpassung der Sattelsituation. Pferdeheilkunde 21, 102-114

Nyikos S., Werner D., Müller J. A., Buess C., Keel R., Kalpen A., Vontobel H-D., von Plocki K. A., Aver J. A., Von Rechenberg B. (2005) Elektronische Satteldruckmessungen im Zusammenhang mit Rückenproblemen bei Pferden. Pferdeheilkunde 21, 187-198

Peham C., Kotschwar A. B., Borkenhagen B., Kuhnke S., Molsner J., Baltacis A. (2010) A comparison of forces acting on the horse's back and the stability of the rider's seat in different positions at the trot. Vet. J. 184, 56-59

Pullin J. G., Collier M. A., Durham C. M., Miller R. K. (1996) Use of force sensing array technology in the development of a new equine saddle pad: static and dynamic evaluations and technical considerations. Equine Vet. J. 16, 207-216

Robert C., Audigiè F., Valette J. P., Pourcelot P., Denoix J.-M. (2001) Effects of treadmill speed on the mechanics of the back in the trotting saddlehorse. Equine Vet. J., 154-159

Von Peinen K. (2006) Sattelpassform - was bringen Computermessungen zusätzlich? 23. FFP-Fortbildungsveranstaltung zur Pferdegesundheit: Wirkung von Sätteln

Von Peinen K., Wiestner T., von Rechenberg B., Weishaupt M. A. (2010a) Relationship between saddle pressure measurements and clinical signs of saddle soreness at the withers. Equine Vet. J.42, 650-653 
Von Peinen K., Ramseier L. C., Waldern N. M., Von Rechenberg B., Aver J. A., Weishaupt M. A. (2010b) Eineinhalb Jahrzehnte Satteldruckmessung - Wissensstand und Nutzen für das Pferd. Pferdeheilkunde 26, 563-568

Werner D., Nyikos S., Kalpen A., Geuder M., Haas C., Vontobel H. D., Aver J. A., von Rechenberg B. (2002) Druckmessungen unter dem Sattel: Eine Studie mit einem elektronischen Sattel-Messsystem (Novel GmbH). Pferdeheilkunde 18, 125-140

Erweiterte Zusammenfassung

\section{Vorläufige Feldstudie zur Satteldruckverteilung bei Pfer- den ohne Rückenprobleme}

Rund $75 \%$ der Pferde werden mit einem unpassenden Sattel geritten, was eine der wesentlichen Ursachen für Rückenprobleme und Leistungsdepression bei Sportpferden ist. Hauptgründe für schlecht passende Sättel sind asymmetrische Sättel, zu harte Sattelkissen, zu enge Sattelkammern und zu weit nach hinten verlagerte Schwerpunkte der Sitzfläche.

Normalerweise wird die Passform eines Sattels durch eine Fachperson subjektiv beurteilt wobei die Begutachtung ausschliesslich im Stand stattfindet. Durch Satteldruckmesssysteme ist es möglich, die Druckverteilung in der Bewegung objektiv zu beurteilen. In den neusten Studien wird das Pliance-System der Firma Novel GmbH verwendet, um Sattelunterlagen, Sattelpassformen, Sattelmarken oder die Evaluation der Interaktion zwischen Reiter und Pferd in hoch standardisierten Studien zu überprüfen. Der Wissensstand über die Aussagekraft, die Verlässlichkeit und die Verwendbarkeit solcher Messmatten ist in stetem Aufbau. Die Standardisierung der Faktoren ist dabei von essentieller Bedeutung. Bei der alltäglichen Arbeit mit solchen Satteldruckmatten sind diese Voraussetzungen nur bedingt gegeben.

Ziel der Studie war es anhand von Satteldruckmessungen zu überprüfen, wie die Druckwerte in einer gesunden Pferdepopulation verteilt sind und ob die Messmatte in einem Feldversuch verlässliche Informationen zur Überprüfung der Sattelpassform liefert. Weiter wurde untersucht, wie Satteltyp, Sattelunterlage und Rückenkonformation die Satteldruckverteilung beeinflussen.

Vierzig zufällig ausgewählte Pferde wurden mit dem System Satteltester ${ }^{\circledR}$ im Stand, Schritt, versammeltem Schritt, Leichttrab und versammeltem Trab auf geraden Linien über 25 Meter untersucht. Die gemessenen Druckwerte wurden im Rückenbereich in prozentuale Anteile vorne-hinten, linksrechts sowie spinal eingeteilt. Zusätzliche Angaben wurden mittels Fragebogen generiert und die erhobenen Daten wurden durch das Analyseprogramm STS 3.42 und NCSS 2007 (ANOVA) ausgewertet.

Die gemessene prozentuale Druckverteilung in craniocaudaler Richtung (vorne-hinten) zeigt Differenzen zwischen allen Gangarten. Ein signifikanter Unterschied wurde jedoch nur zwischen dem Stand und dem Leichttrab $\left(p=0.027^{*}\right)$ im vorderen Bereich festgestellt (Abb. 1 und Tab. 1). Keine signifikanten Unterschiede konnten in der prozentualen links-rechts Verteilung der Mediane festgestellt werden (Abb. 2). Der optimale Wert von $50 \%$ mit Abweichungen bis zu $10 \%$ zu beiden
Seiten konnten bestätigt werden. In Abbildung 3 sind die prozentualen Druckwerte auf der Wirbelsäule in allen gemessenen Gangarten zu erkennen. Signifikant tiefere Werte wurden während dem Leichttrab und dem versammelten Trab gegenüber dem Stand $\left(p=0.000131^{*}\right)$ festgestellt. Der Mittelwert der prozentualen Druckverteilung liegt bei $11.5 \%$.

Verglichen mit dem Dressursattel, dem Springsattel und dem Vielseitigkeitssattel zeigten Westernsättel im Stand ( $p=0.003$ ) sowie Schritt $(p=0.0136$ und $p=0.003)$ signifikant höhere Druckwerte im Widerristbereich (Tab. 2). Eine weitere signifikante Differenz wurde zwischen der prozentualen links-rechts Verteilung zwischen den Western- sowie baumlosen Sätteln gegenüber den anderen Sätteln festgestellt $(p=0.001$, $p=0.005)$. Des Weiteren wies der baumlose Satteltyp eine erhöhte Druckverteilung im spinalen Bereich auf (Tab. 2). Der höchste Druckwert wurde im Stand mit 40.3\% gemessen.

Im Gegensatz zur einfachen Schabracke erhöhten Sattelunterlagen wie Gelpads, Schaumstoff- oder Jogamatten die Druckverhältnisse im vorderen Bereich und über die Wirbelsäule während dem Stand und Schritt signifikant $(p<0.05)$ (Tab. 3).

Eine eingefallene Rückenkonformation (fehlende Bemuskelung) resultierte im Lendenwirbelbereich in prozentual höheren Druckwerten als ein runder Rücken (gute Bemuskelung) (Tab. 4). Diese Druckverteilung konnte über alle fünf Gangarten festgestellt werden $(p=0.021, p=0.023, p=0.015$, $p=0.017, p=0.022)$.

Unabhängig von der Gangart kann eine Variabilität von bis zu $30 \%$ in der Druckverteilung vorne-hinten als normal gesehen werden. Diese Erkenntnisse decken sich mit anderen Studien, welche eine hohe Variabilität der Maximaldruckwerte von 23 bis $25 \%$ beschreiben. Die Verteilung der Messwerte "links-rechts" ist, bei Vernachlässigung der Ausreißer, sehr gering. Abweichungen von rund $5-10 \%$ sind normal. Um die Ausreißer richtig einzuschätzen und zu interpretieren, muss das klinische Bild berücksichtig werden. Sofern Auffälligkeiten wie Scheverstellen, weisse Flecken oder Dolenz vorhanden sind, gilt es diese Ausreißer als abnormal einzustufen. Im spinalen Bereich sollte grundsätzlich kein Druck einwirken, was durch einen genügend breiten Kissenkanal erreicht werden kann. Trotz eines gewünschten Druckwertes von 0\%, lag der Durchschnitt über alle Faktoren auch in der vorliegenden Studie bei $11.5 \%$. Ebenfalls wurde festgestellt, dass die spinale Belastung über die Gangarten vom Stand hin zum Trab abnahm. Eine mögliche Erklärung ist der vermehrte Schwung und die erhöhte Muskelaktivität sowie größere Spannung der Rumpfmuskulatur im Trab, welche zu einer Entlastung der Wirbelsäule führen.

Wie bereits erwähnt, weist die Studie im vorderen Bereich konstant höhere Druckwerte auf. Die höheren Messwerte können einerseits auf den Reiter und seinen Sitz zurückgeführt werden, welcher einen großen Einfluss auf die Messdaten hat und andererseits auf die Instabilität eines schlecht passenden Sattels. Der Druck steigt vom Stand über den Schritt bis hin zum Leichttraben und nimmt im ausgesessenen Trab wieder ab. Resultate aus anderen Studien belegen dieses Ergebnis. Nicht nur die Gangart, sondern auch die Geschwindigkeit beeinflussen die Spannung und Schwingung im Pferderücken 
und dadurch auch die Druckverteilung. In der vorliegenden Studie wurde die Geschwindigkeit nicht standardisiert. Die Tiere liefen in dem ihnen entsprechenden Tempo.

Dressursättel scheinen im Stand und im Schritt mit Werten um die 50:50 den Druck am besten zu verteilen. Neben einem gut passenden Sattel ist vor allem in dieser Disziplin ein korrekter Sitz von zentraler Bedeutung, was sich auch in der Messung wiederspiegeln kann. Signifikant höhere Druckwerte wurden im vorderen Bereich bei den drei Westernsätteln im Vergleich zu allen anderen Sätteln gemessen. Andere Studien bestätigen das nach vorne Verkippen, wobei die Ursache im starren Sattelbaum liegen kann. Im Bereich "links-rechts" zeigt sich ein signifikanter Unterschied im Schritt. Die Westernsättel und der baumlose Sattel scheinen ein Problem in ihrer Stabilität zu haben. Schlussendlich führt ein fehlender Sattelbaum zu einer schlechteren Gewichtsverteilung, einer punktuellen Auflage und dem gemessenen signifikant höheren Druckwert über der Wirbelsäule. Trotz der geringen Anzahl $(n=3, n=1)$ wurden dieselben Tendenzen wie in anderen Studien festgestellt und es empfiehlt sich den oben genannten Problemen bei einer Sattelanpassungen besondere Beachtung zu schenken.

Ein gut angepasster Sattel ist von zentraler Bedeutung wobei Sattelunterlagen nicht oder nur in geringem Maße in der Lage sind Druckstellen auszugleichen. Hingegen beeinflussen Sattelunterlagen (Gel, Leder, Schaumstoff oder Rentierfell), welche an einen gut passenden Sattel angepasst sind, die Sattelpassform nicht im negativen Sinne. Lediglich das Rentierfell scheint jedoch im Stande den Maximaldruck zu senken. Die verwendeten Sattelunterlagen müssen ausreichend groß sein, die richtige Form im Widerristbereich aufweisen und dürfen den Sattel nicht einengen. Unter Berücksichtigung dieser Gegebenheiten besteht eine negative Beeinflussung durch die "alternativen" Sattelunterlagen (Tab. 3) auf die prozentuale Druckverteilung (signifikante Druckerhöhung nach vorne sowie über der Wirbelsäule). Ein gut angepasster Sattel mit einer einfachen, dünnen Schabracke scheint die beste Lösung für eine ausgeglichene Druckverteilung zu sein.
Die Konformation des Pferderückens respektive die Bemuskelung des Pferdrückens verlangen bei der Sattelanpassung besondere Aufmerksamkeit. Bei Pferden mit mangelnder Rückenmuskulatur verkippt der Sattel nach hinten und übt vermehrten Druck auf den sensiblen Lendenbereich aus, was wiederum zu Verspannungen des M. longissimus dorsi führt. Ein runder Rücken hingegen verlagert das Reitergewicht vermehrt auf den Widerristbereich.

Da die Studie zum Ziel hatte, den Wert von elektronischen Satteldruckmessungen für Sattler oder Trainer unter alltäglichen Bedingungen zu überprüfen, wurden die vierzig Pferde nicht klinisch auf Rückenprobleme untersucht. Daher können Rückenprobleme in der thoracolumbaren Region nicht ausgeschlossen werden. Eine klinische Untersuchung sowie Röntgenbilder des thoracolumbar vertebral column wären hierfür nötig gewesen.

Des Weiteren wurden die Tiere zufällig ausgewählt und mussten keine Vorgaben erfüllen. Dadurch konnte eine Voreingenommenheit verhindert werden, was jedoch zu relativ tiefen Zahlen in den einzelnen Kategorien führte und einer damit verbundenen schlechten Aussagekraft. Dennoch konnten wichtige Tendenzen aufgezeigt werden. Zukünftige Studien sollten aber eine höhere Anzahl Pferde einschließen.

Die Untersuchung unterteilte den Rücken in die Kategorien vorne-hinten, links-rechts sowie spinal. Für eine bessere Eingrenzung der abnormalen Druckwerte wäre eine feinere Unterteilung der Rückenbereiche sinnvoll. Obschon das verwendete System nicht in der Lage ist absolute Druckwerte zu liefern, konnten wichtige zusätzliche Informationen bezüglich der auf den Rücken wirkenden Kräfte ermittelt werden.

Die Untersuchung ergab bei Messungen unter Praxisbedingungen erste wertvolle Hinweise auf Satteldruckverteilungen und beeinflussende Faktoren bei gesunden Pferden. Weitere Untersuchungen einer größeren Pferdeanzahl können eine zuverlässigere Interpretation mit verbesserter klinischer Relevanz ermöglichen. 